УДК 159.9:376

doi: $10.15330 /$ ps.10.1.166-171

Алла Ковтун

ДВНЗ «Прикарпатський національний університет імені Василя Стефаника» olegkovtyn2010@ukr.net

\title{
ПСИХОЛОГІЧНІ АСПЕКТИ ІНДИВІДУАЛЬНОГО ПІДХОДУ В ІНКЛЮЗИВНІЙ ОСВІТІ
}

\begin{abstract}
У статті здійснюється спроба теоретичного аналізу проблеми індивідуального підходу до учнів та його ефективності в проиесі інклюзивної освіти. Аналізуються особливості індивідуальної освітньої програми, яка є результатом командної роботи фахівців. Саме иеей документ є важливим для планування $i$ оиінки освітніх послуг. Розглядається результативність співпрачі учителя $i$ психолога на прикладi вітчизняних та зарубіжних наукових шкіл, досвід роботи в корекиійних класах $i$ загальноосвітніх класах 3 включенням проблемних дітей. Адже взаємодія психолога з педагогом дозволяє педагогу більш глибоко зрозуміти особливості спільної діяльності вчителя $і$ учня та беззаперечну необхідність вчительської допомоги, використання ним гнучкого підходу до особливостей всіх учнів. В роботі звертається увага на те що, реалізація теоретичних та практичних основ діагностики стану вищих психічних функцій дітей дозволяє спільно педагогу і психологу вирішити питання з підбору методик, градаиії складності завдань, які вводяться, наочного і вербального матеріалу, а також способу його подачі, щзо підвищує можливості самої дитини. Підкреслюється необхідність напрачювання спільної стратегії роботи класу, підвищення зацікавленості та мотивації дитини до занять за рахунок використання сюжетних, ігрових методів навчання, реалізаиії принципу міжпредметних зв 'язків на всіх заняття, врахування індивідуальних особливостей дітей під час очінювання, щзо дозволяє підкреслити будь-які, навіть незначні успіхи кожної дитини. Аналіз джерел дає підстави сформувати уявлення про переваги інклюзивного навчання, а також про планування спільних дій у напрямі пристосування інклюзивного навчання до умов української иколи.

Ключові слова: інклюзивна освіта, індивідуальний підхід, індивідуальна освітня програма, взаємодія, психолог, учитель, учень, вищі психічні функиії, навчальне навантаження, оцінка, оцінювання.
\end{abstract}

Постановка проблеми. Удосконалення виховання і навчання підростаючого покоління є одним з найважливіших шляхів підвищення ролі людського фактора. Визначальною умовою існування й розвитку людини як особистості є багатопланова діяльність, що здійснюється в процесі спілкування з іншими людьми. Реальним базисом особистості людини є сукупність іï ставлень до світу, які реалізуються ії діяльністю, точніше, сукупністю іiі різноманітних діяльностей.

Спілкування є однією з найважливіших умов об'єднання людей для спільної діяльності, в тому числі для навчання і виховання як опосередкованої спілкуванням спільної діяльності вчителя і учня.

Умови нашого сьогодення вимагають від освітнього простору впровадження та використання нових методів і підходів в роботі з дітьми. Особливо це стосується інклюзивного напрямку освіти, який тільки розвивається в Україні. Досвід і надбання вітчизняних і зарубіжних практик дозволяє розширити розуміння особливостей використання індивідуального підходу в освітньому процесі. Тому актуальною постає проблема психологічних аспектів індивідуального підходу в інклюзивній освіті.

Інклюзивна освіта не може бути ефективною без індивідуального підходу до учнів, про необхідність якого одностайно говорять вітчизняні та зарубіжні методисти та практики. Науково-методичною базою індивідуалізації навчання може бути психологічний підхід до діагностики та розробки ефективних стратегій навчання. Як він може бути реалізований?

Основним документом, що фіксує індивідуальний підхід до навчання, є індивідуальна освітня програма (IOП). Безумовно, ІОП повинна містити відомості, чим повинен володіти даний учень в кінці навчального року. А ось варіативність шкільних програм необхідна особливість інклюзивного навчання. Але цілі програми не будуть досягнуті без вказівки на шляхи і методи вирішення поставлених завдань. 
Мета дослідження полягає у вивченні досвіду вітчизняних та зарубіжних науковців, який дозволить збільшити спектр вибору шляхів і методів роботи в інклюзивній освіті, що передбачає врахування індивідуальних особливостей когнітивних процесів і поведінки школяра.

Виклад основного матеріалу. Найбільш ефективні методи інклюзивної освіти розроблені в психології не тільки вітчизняними науковцями, але величезні надбання мають $\mathrm{i}$ європейські держави, приклад і досвід яких заслуговує на увагу. Для цих країн навчання дітей з особливими потребами разом зі здоровими однолітками має особливе значення, адже спілкування зі здоровими однокласниками та їх психологічна підтримка - найголовніше в інклюзивній освіті. Наприклад, Італія як одна 3 «локомотивів» запровадження інклюзивного навчання визнала цей вид навчання для дітей з обмеженими можливостями одним 3 найкращих варіантів здобуття ними освіти. В Австралії підтримку дітям з обмеженими можливостями надають профільні спеціалісти з медичних та медико-соціальних установ, використовуючи напрацьований індивідуальний підхід у роботі з дітьми. Свої системи інклюзивного навчання та власні підходи є в Ірландії, Німеччині, Ісландії, Іспанії, Великобританії, Голландії, Швеції та США. Як видно із вище зазначеного, кількість зарубіжних країн, які мають що представити в якості досвіду інклюзивного навчання для України, досить велика. Для прикладу розглянемо інклюзивну систему в США.

В американських школах індивідуальну освітню програму (IOП) створює команда фахівців. Вона затверджується раз на рік на спільному засіданні, і в ній містяться такі розділи:

1. Дані про наявний рівень знань і успішності навчання учня (academic achievement) і його функціональні можливості (functional performance), що передбачає опис, як вони впливають на залучення дитини до навчального процесу та іiі успішність в оволодінні загальноосвітньою програмою, на її роль в колективі класу та їі домашні обов'язки.

2. Вимірювані цілі програми навчального року (навчальні та / або функціональні).

3. Опис, як буде вимірюватися прогрес у досягненні цілей програми.

4. Необхідне спеціальне і додаткове навчання з описом модифікації програми $\mathrm{i}$ додаткової допомоги, що надається персоналом школи при освоєнні загальноосвітньої програми і при додаткових заняттях.

5. Перелік занять класу, в яких учень не братиме участі.

6. Опис того, які можливості будуть надані учневі при написанні контрольних робіт (наприклад, збільшення часу). Примітка: якщо учень не може брати участь в контрольних роботах, які альтернативні способи будуть використані.

7. Дати початку, завершення і частоти додаткових занять.

Цей документ, важливий для планування (і перевірки) освітніх послуг, також включає опис сильних і слабких сторін дитини, запит батьків, результати найновіших обстежень, стратегії допомоги дитині, мовний і комунікативний статус та необхідність допомоги [8, с. 75-77].

Аналіз досвіду роботи в корекційних класах і загальноосвітніх класах українських шкіл з включенням проблемних дітей показує, що виявлення сильних і слабких сторін дитини і розробка стратегії допомоги дитині найефективніше здійснюється при взаємодії педагогів і психологів.

У психології розроблені як теоретичні та практичні основи діагностики стану вищих психічних функцій (ВПФ) дітей, так і теорія і методи корекційної роботи з подолання невстигання у розвитку ВПФ.

Психологічний аналіз стану ВПФ дозволяє виявити сильні і слабкі сторони розвитку кожної дитини, встановити якісну специфіку недорозвитку, прогнозувати майбутні труднощі в становленні пізнавальних процесів. Психологічна діагностика включає не тільки тестові методи, але і методи «спостережливої діагностики», тобто метод спостереження за поведінкою дитини під час роботи і відпочинку та аналіз виконання навчальних і творчих завдань. Така діагностика проводиться психологом і педагогом спільно. Вона 
передбачає надання дитині різних видів допомоги і аналіз того, що саме допомагає дитині. Тому суттєву роль у спостереженні за дитиною та адаптації іiі до шкільного навчання відіграє саме педагог, який володіє багатим арсеналом методів з розвитку активності, самостійності дитини, ії пізнавальної сфери.

Отже, взаємодія психолога з педагогом полягає у спільному виявленні не тільки особливостей вищих психічних функцій (ВПФ) дитини, що ведуть до іiі недостатньої спроможності, а й «яким чином і за яких умов можливе подолання труднощів, як зробити крок від неуспіху до успіху. Спільно вирішуються завдання по підбору методик, градації складності завдань, що вводяться, наочного і вербального матеріалу, а також способу його подачі, що підвищує можливості дитини у виконанні завдань « [3].

На основі отриманих індивідуальних даних після спільного обговорення педагогом і психологом сильних і слабких ланок ВПФ кожної дитини може бути вироблена спільна стратегія роботи класу, поділ його на групи за проблемами. До речі, під час вивчення різних предметів склад груп може змінюватися. При складанні програми занять враховується, що в класі одночасно будуть перебувати діти як із загальними, так і з індивідуальними труднощами.

Як правило, загальними особливостями сучасних дітей є труднощі довільної організації, сповільненість або імпульсивність, легке відволікання, швидка стомлюваність, труднощі концентрації уваги, наростання труднощів під час тривалого виконання завдань однієї модальності і знижений рівень мотивації навчальної діяльності.

До індивідуальних особливостей можуть відноситися складності з переробкою слухової або зорової інформації. Якщо педагог використовує на занятті систему методів, спрямовану на компенсацію труднощів засвоєння зорової інформації, то інші діти в цей момент можуть залишитися без уваги, і навпаки. Тому під час складання програми роботи потрібно враховувати всі компоненти, які утворюють психічну функцію, що засвоюється. Якщо в однієї дитини або групи дітей проявляються свої специфічні труднощі, педагог повинен допомагати їм опрацювати кожну ланку цієї психічної функції. Інші діти в цей момент мають можливість вдосконалювати навички самостійної роботи в заданому виді діяльності, який дається їм відносно легко.

В цілому стратегія роботи 3 класом інклюзивного навчання передбачає, що організація занять повинна базуватися на методах роботи, які спираються на збереження сильних ланок і поступово втягують у роботу слабкі ланки. Для реалізації такого підходу можуть бути використані системи методів для «вирощування» слабкої ланки. Педагог, навчаючи дітей будь-якої навички, вибудовує систему взаємин дорослий-дитина, де дорослий бере на себе функції слабкої ланки, поступово передаючи все більшу частину функцій дитині.

Відповідно до положення Л. С. Виготського про «подвійне» народження вищих психічних функцій («перший раз» - у взаємодії між людьми, «другий» - у внутрішньому плані) виникає необхідність звернутися до нього в розгляді окресленої теми. Особливість цього явища полягає у створенні і реалізації суб'єктом системи спеціальних психологічних комунікативних засобів, «через» які опосередковується міжособистісний контакт і досягається не лише взаєморозуміння, а й цікаве явище «взаємного саморозвитку» партнерів спілкування.

Згідно $з$ цим положенням Л. С. Виготського завдання в інклюзивному навчанні повинні варіювати від простого до складного за такими параметрами:

- спільні - самостійні (від розподілу функцій між тим, хто навчає, і тим, кого навчають, через поступове скорочення ролі того, хто навчає, до самостійної дії);

- зовні опосередковані - внутрішні (від дій із залученням зовнішніх матеріалізованих опор, зовнішньої програми до внутрішньої, виконуваної в умі дії);

- розгорнуті - згорнуті (від розгорнутого поелементного виконання і контролю дії до їх згорнутих форм). 
Особлива увага під час складання програми роботи групи має приділятися підбору навчального та наочного матеріалу. Оскільки для подолання своїх труднощів кожній дитині потрібна своя опора, необхідно підбирати (створювати) навчальні матеріали та навчальні види діяльності, представлені на слуховій, зоровій і тактильній основі. Досвід показує, що такий метод допомагає кожній дитині успішно вирішувати пізнавальні завдання і знаходити свої шляхи для компенсації слабкої ланки.

Для підвищення інтересу дитини до занять рекомендується використовувати ігрові, сюжетні методи навчання, включати завдання у смисловий контекст, поступово переводячи виконання від емоційно забарвленого у більш довільний план. Необхідно створювати умови, в яких менше виявлялися б нейродинамічні порушення дітей, натомість підвищувалася б їх пізнавальна активність, формувалася б навчальна мотивація.

Для забезпечення гнучкого підходу до особливостей всіх учнів рекомендують створювати такі умови:

1. Простір класу ділиться на зони: навчальну й ігрову. Це дає можливість проводити заняття з частиною дітей не тільки за партою, а й на підлозі або за ігровим столом, допомагає знизити труднощі утримання пози за партою протягом 40 хвилин, варіювати тривалість навчального навантаження для різних категорій дітей.

2. У класі вводяться правила поведінки, з якими ознайомлені діти, батьки, вчителі. Правила поведінки в класі є загальними для всіх, в тому числі і для вчителя. Наприклад, якщо в правилах поведінки записано, що в класі не можна кричати, то ніхто (в тому числі і вчитель) не кричить. Правила не можна вводити довгим списком. Одночасно можна прийняти одне-два правила. Наступні можна вводити тільки після того, як засвоєні вже прийняті правила.

3. 3 огляду на специфіку віку та індивідуальні особливості дітей можна створювати ощадний режим навантажень. Залежно від стану дітей і змісту конкретного заняття на початковому етапі вони можуть тривати різний час - від 25 до 40 хвилин. Заняття можуть не ділитися на предмети і не об'єднуватися єдиним сюжетом. На всіх заняттях повинен реалізуватися принцип міжпредметних зв'язків. На початковому етапі частка ігрових ситуацій може переважати над навчальними завданнями. Поступово емоційне і безпосереднє виконання завдань повинно переходити у більш довільний план.

4. Учитель повинен ставити перед собою завдання соціалізації дітей. Зміни спрямовані не тільки для того, щоб діти могли відновити сили і поспілкуватися, а й набували навичок взаємодії, вчилися правильно поводитися по відношенню один до одного.

5. Особлива увага повинна приділятися підбору наочного навчального матеріалу. До критеріїв оцінки адекватності навчальних матеріалів процесу інклюзивного навчання відносять: рівень змістовної складності; зорова насиченість; розмір шрифту; наявність упізнавання образів; смислове використання кольору; орієнтація на дитину - правша чи лівша (шульга); різнорівневість (придатність для використання дітьми з різними рівнями когнітивного розвитку) і вичерпність матеріалів; частотність вживаних слів; емоційний тонус. Дуже важливою $є$ зорієнтованість наочних матеріалів на особистий досвід і інтереси дітей. Багато наочних матеріалів учні можуть зробити в класі спільними зусиллями, наприклад, «числовий ряд», «круглий рік», і це збільшує інтерес до них.

6. Необхідно враховувати індивідуальні особливості дітей, низький рівень мотивації, емоційну нестабільність. Тому система оцінки повинна підкреслювати будь-які, навіть найнезначніші успіхи кожної дитини. Дуже важливо розвести в розумінні дітей і батьків поняття «оцінка» та «оцінювання». Ми оцінюємо не дитину, а результати ії діяльності. «Оцінювання» може бути високим при низькій «оцінці». Оцінка може бути бальною та матеріальною - красива наліпка, картинка-штамп, маленький подарунок. Рекомендується також організовувати виставки дитячих робіт. Кожна робота розглядається усіма дітьми, в кожній можна знайти що-небудь хороше. Поступово діти вчаться оцінювати свої роботи і порівнювати їх з роботами інших дітей. 
7. В даний час психодидактичні методи все більше впроваджуються не тільки в діагностичну, але і в корекційну роботу з дітьми з певними відхиленнями від норми. Існує цілий спектр методик, які активно застосовуються як при індивідуальній корекції, так і при груповій роботі, у тому числі в початкових класах школи [1; 2; 4-6; 7].

Висновки. Багаторічний досвід застосування методів психологічної корекції в педагогічній практиці показує, що спільна робота педагога і психолога створює умови для успішного навчання різних категорій дітей з особливими потребами, що формує стратегію подальшого розвитку інклюзії в Україні.

По-перше, тлумачення інклюзивного навчання. Інклюзивне навчання означає, що всі учні отримують освіту в звичайних класах. Це не означає, що учень не може залишити клас 3 якихось певних причин. Кожен учень може отримати індивідуальну допомогу 3 того чи іншого предмету. Якщо система освіти є інклюзивною, це не означає, що учні можуть розподілятися по групах за своїми характеристиками в окремих класах на цілий день або пів дня. В інклюзивному класі умови створюються для всіх учнів так, щоб вони навчалися разом. Інклюзивне навчання не розділяє учнів у класі.

По-друге, переваги інклюзивного навчання. Всі діти отримують користь від інклюзивного навчання. Воно дозволяє їм розвивати індивідуальні сильні сторони і таланти, приймати всіх дітей без винятку в загальноосвітню шкільну систему і суспільство; працювати над досягненням індивідуальної мети, беручи участь у житті громади та їхнього класу; залучати батьків у процес навчання і життя школи; розвивати культуру поваги i належності до школи, мати змогу навчатися і поважати різні здібності інших; зав'язувати дружні стосунки $з$ іншими дітьми; позитивно впливати на школу, громаду та поважати різноманіття та включення на більш широкому рівні, спільні дії в просуванні інклюзивного навчання; приймати всіх дітей до загальноосвітніх шкіл та шкільного життя; надавати всебічну допомогу учням з особливими потребами, їх одноліткам та вчителям у разі потреби; дивитися на кожного учня з огляду на те, що він може, а не на те, чого він не може; формулювати навчальні цілі згідно з індивідуальними можливостями кожної дитини, беручи до уваги, що діти можуть мати різні навчальні цілі, але навчатися разом в одному класі; переобладнати школи і класи з тим, щоб вони зосереджували увагу на потенціалі кожної дитини; сприяти сильному лідерству в особі директора школи і адміністрації; сприяти підготовці вчителів, які ознайомлені з різними методами викладання; формувати команду - директорів шкіл, вчителів, батьків, учнів та інший персонал, що працюють разом у визначенні найефективніших шляхів надання якісної освіти в інклюзивному середовищі; підтримувати виважене ставлення до батьків, особливо до мрій батьків та цілей щодо майбутнього їхніх дітей [9].

Такий індивідуальний підхід в інклюзивній освіті повинен базуватися на багаторічному досвіді як зарубіжних, так і вітчизняних практиків у роботі з дітьми з особливими потребами. Вивчення напрацювань, які успішно застосовуються в царині інклюзивного навчання, а в подальшому і відкриття нових можливостей для забезпечення індивідуального підходу - перспективний шлях розбудови інклюзивної освіти в Україні.

1. Ахутина, Т. В., Пылаева, Н. М. (2008). Преодоление трудностей учения: нейропсихологический подход. Санкт-Питербург: Питер.

2. Ахутина, Т. В., Манелис, Н. Г., Пылаева, Н. М., Хотылева, Т. Ю. (2006). Скоро школа. Путешествие Бима и Бома в страну математику. Методическое пособие и рабочая тетрадь. Москва: Теревинф.

3. Пылаева, Н. М. (1995). Опыт иейропсихологического исследования детей 5-6 лет с задержкой психического развития. Вестник Москосковского университета. Психология, 3 (14), 37-45.

4. Пылаева, Н. М., Ахутина, Т. В. (2006). Школа умножения. Методика развития внимания у детей 7-9 лет. Москва: Теревинф.

5. Пылаева, Н. М., Ахутина, Т. В. (2008). Школа внимания. Методика развития и коррекиии внимания у детей 5-7 лет. Санкт-Питербург: Питер.

6. Пылаева, Н. М., Ахутина, Т. В. (2008). Учимся видеть и называть. Развитие зрительновербальных функций у детей 5-7 лет. Санкт-Питербур: Питер.

7. Хотылева, Т. Ю., Пылаева, Н. М. (2010). Графические диктанты. Москва: ГОУ ЦПМССДиП.

8. Detrich, R. (2008). From policy ty practice: IDEIA and evidence-besed practice. In:Educating 
individuals with disabilities: IDEIA 2004and beyond. Ed by Elena L. Grigorenko,N.Y. Springer Pablishing Compani.

9. Що таке інклюзивна навчання? Інклюзивна освіта: поширені питання (2019). Взято із https://education-inclusive.com/network.

\section{REFERENCES}

1. Ahutina,T. V., Pylaeva, N. M. (2008). Preodolenie trudnostej uchenija: nejropsihologicheskij podhod [Overcoming Learning Difficulties: A Neuropsychological Approach]. Sankt-Piterburg: Piter. (rus.).

2. Ahutina, T. V., Manelis, N. G., Pylaeva, N. M., Hotyleva, T. Ju. (2006). Skoro shkola. Puteshestvie Bima i Boma v stranu matematiku. Metodicheskoe posobie i rabochaja tetrad' [School is coming soon. The journey of Bim and Bohm to the country of math. Methodical manual and workbook]. Moskva: Terevinf. (rus.).

3. Pylaeva, N. M.(1995). Opyt iejropsihologicheskogo issledovanija detej 5-6 let s zaderzhkoj psihicheskogo razvitija [Experience in a neuropsychological study of children 5-6 years of age with mental retardation]. Vestnik Moskovskogo unsversiteta Psihologija [Bulletin of Moscow University. Psychology], 3 (14), 37-45. (rus.).

4. Pylaeva, N. M., Ahutina, T. V. (2006). Shkola umnozhenija. Metodika razvitija vnimanija u detej 7-9 let [ School of Multiplication. Methods of attention development in children 7-9 years old]. Moskva: Terevinf. (rus).

5. Pylaeva, N. M., Ahutina, T. V. (2008). Shkola vnimanija. Metodika razvitija i korrekcii vnimanija u detej 5-7 let [School of attention. Development and correction technique of attention in children 5-7 years old]. Sankt-Piterburg: Piter. (rus.).

6. Pylaeva, N. M., Ahutina, T. V. (2008). Uchimsja videt' i nazyvat'. Razvitie zritel'no-verbal'nyh funkcij u detej 5-7 let [Learning to see and call. Visual and verbal functions development in children 5-7 years old]. SanktPiterbur.: Piter. (rus.).

7. Hotyleva, T. Ju., Pylaeva, N. M.(2010). Graficheskie diktanty [Graphic dictations]. Moskva: GOU CPMSSDiP. (rus.).

8. Detrich, R.(2008). From policy ty practice: IDEIA and evidence-besed practice. In: Educating individuals with disabilities: IDEIA 2004and beyond. Ed by Elena L. Grigorenko, N. Y. Springer Pablishing Compani.

9. Shho take inkljuzivna navchannja? Inkljuzivna osvita: poshireni pitannja [What is inclusive study? Inclusive education: frequently asked questions]. (2019). Retrieved from https://education- inclusive.com/network. (ukr.).

\section{Alla Kovtun \\ PSYCHOLOGICAL ASPECTS OF INDIVIDUAL APPROACH IN INCLUSIVE EDUCATION}

The article attempts to theoretically analyze the problem of an individual approach to pupils and its effectiveness in the process of inclusive education. The features of an individual educational program, which is the result of teamwork of specialists, are analyzed. This document is important for planning and evaluation educational services. The article considers the effectiveness of cooperation between a teacher and a psychologist on the example of domestic and foreign scientific schools, experience in correctional classes and general education classes with the inclusion of problem children. After all the interaction of a psychologist with a teacher allows the teacher to understand more deeply features of joint activity of the teacher and the pupil and an undisputed need of having the teacher's help and using a flexible approach to the characteristics of all pupils. The work draws attention to the implementation of theoretical and practical basics of diagnostics of the state of the higher mental functions of children. It allows the teacher and the psychologist together to solve the problem of selection of techniques and methods, gradation of difficulties of the tasks, visual and verbal material, and also the method of its submission which enhances the child's capabilities. The importance of developing a common classroom strategy is emphasized. Increasing the interest and motivation of a child to the classroom by using stories and games as teaching methods. Implementation of the principle of interdisciplinary relations in all classes. Taking into account the individual characteristics of children during the evaluation allows you to emphasize any successes of each child even the most insignificant ones. The analysis of the sources gives grounds to form a vision and advantages of inclusive education, as well as planning joint actions in the adaptation of inclusive education in the Ukrainian school.

Keywords: inclusive education, individual approach, individual educational program, interaction, psychologist, teacher, student, higher mental functions, study load, assessment, evaluation. 